УДК 364.4:343.81

DOI https://doi.org/10.32782/humanitas/2021.3.2

\title{
Олена БАЛДИНЮК
}

кандидат педагогічних наук, доцент, дочент кафедри соиіальної педагогіки та соиіальної роботи, Уманський державний педагогічний університет імені Павла Тичини, вул. Садова, 28, м. Умань, Черкаська область, Украӥна, 20300

ORCID: 0000-0003-4276-7819

Бібліографічний опис статті: Балдинюк, О. (2021). Соціальна робота в закладах пенітенціарної системи. Ввічливість. Humanitas, 3, 10-16, doi: https://doi.org/10.32782/humanitas/2021.3.2

\section{СОЦАЛЬНА РОБОТА В ЗАКЛАДАХ ПЕНІТЕНЦАРНОЇ СИСТЕМИ}

У статті розглядаються питання соиіальної роботи у пенітениіарних закладах, визначається ї̈ мета, аналізуються основні технології соціальної роботи у иій системі. Метою дослідження є аналіз професійної діяльності соиіальних працівників у пенітенціарних закладах.

Методами дослідження є: аналіз, порівняння й узагальнення джерел із досліджуваної проблеми.

Соціальна робота із засудженими є одним із видів пенітенціарної роботи, яку можна визначити як специфічний вид професійної діяльності, щзо включає в себе: соиіальну допомогу, підтримку, захист засуджених, допомогу у трудовому та побутовому влаштуванні осіб, які звільнилися із місиь позбавлення волі, а також їх адаптацію у суспільстві після звільнення.

Науковою новизною дослідження є те, щุо охарактеризовано особливості соиіальної роботи в закладах пенітениіарної системи (поширеність тюремної, кримінальної субкультури; криміногенне міжособистісне спілкування, а також обмеженість нормального спілкування; поширеність кримінальних способів вирішення суперечностей; наявність різних форм насильства; несприятливий соиіально-психологічний клімат; підвищений ризик зазнати насильства, образи, утиску людської гідності).

Особлива увага приділяється спещифіці діяльності соціальних працівників у пенітенціарних закладах, освоєнню нових професійних компетентностей, оновленню теоретичних і практичних знань фахівиів у зв'язку із вимогами до рівня кваліфікації та необхідністю освоєння сучасних методів вирімення професійних завдань. Уточнено принципи роботи сочіального працівника у пенітенціарних закладах, а саме: універсальності, охорони соціальних прав, профілактики, соціального реагування, клієнтоцентризму, конфіденційності, толерантності, опори на власні сили та принции максимізації соиіальних ресурсів.

Результати дослідження показали, щуо важливими видами діяльності, які здійснює фахівець із сочіальної роботи із засудженими, є стратегічне планування; оцінка потреб засудженого; робота із сім'ями засуджених тощзо. Охарактеризовано складники професійної культури соиіального працівника: особистість самого соиіального прачівника пенітенціарної установи, його теоретичний і практичний професійний досвід, розвинені особистісні якості.

Ключові слова: пенітенціарна система, засуджені, сочіальна реабілітація, соціальний працівник, напрями соиіальної роботи у пенітенціарних закладах.

\section{Olena BALDYNIUK}

PhD in Pedagogical Sciences, Associate Professor, Associate Professor at the Department of Social Pedagogy and Social Work, Pavlo Tychyna Uman State Pedagogical University, 28 Sadova str., Uman, Cherkasy region, Ukraine, 20300

ORCID: 0000-0003-4276-7819

To cite this article: Baldyniuk, O. (2021). Sotsialna robota v zakladakh penitentsiarnoi systemy [Social work in the institutions of the penitentiary system]. Vvichlyvist. Humanitas, 3, 10-16, doi: https://doi.org/10.32782/humanitas/2021.3.2

\section{SOCIAL WORK IN THE INSTITUTIONS OF THE PENITENTIARY SYSTEM}

The article considers the issues of social work in penitentiary institutions, defines its purpose, analyzes the main technologies of social work in this system. The purpose of our study is to analyze the professional activities of social workers in prisons.

Research methods are: methods of analysis, comparison and generalization of sources on the researched problem.

Social work with convicts is one of the types of penitentiary work, which can be defined as a specific type of professional activity, which includes: social assistance, support, protection of convicts, assistance in employment and housing of persons released from prisons, as well as their adaptation in society after liberation. 
The scientific novelty of the study is that the features of social work in the penitentiary system (widespread prison, criminal subculture; criminogenic interpersonal communication, as well as limited normal communication; the prevalence of criminal ways of resolving contradictions; the presence of various forms of violence; unfavorable social climate; increased risk of violence, insults, violation of human dignity).

Particular attention is paid to the specifics of social workers in penitentiary institutions, the development of new professional competencies, updating the theoretical and practical knowledge of specialists in connection with the requirements for the level of qualification and the need to master modern methods of solving professional problems. The principles of work of a social worker in penitentiary institutions are specified, namely: universality, protection of social rights, prevention, social response, client-centeredness, confidentiality, tolerance, self-reliance and the principle of maximizing social resources).

The results of the study showed that strategic planning is an important activity carried out by a specialist in social work with convicts; assessment of the convict's needs; work with families of convicts, etc. The components of the professional culture of a social worker are characterized: the personality of the social worker of the penitentiary institution, his theoretical and practical professional experience, developed personal qualities.

Key words: penitentiary system, convicts, social rehabilitation, social worker, directions of social work in penitentiary institutions.

Актуальність проблеми дослідження. Соціальна робота з різними категоріями населення $€$ ефективним механізмом реалізації соціальної політики щодо незахищених верств населення.

Одним із актуальних напрямів, де соціальний працівник виступає затребуваним фахівцем, є пенітенціарна сфера професійної діяльності. Соціальна робота у виправних установах $€$ особливим великим розділом цього виду професійної діяльності.

Процеси гуманізації та розвиток демократичних засад, які зумовлюють реформування кримінально-виправної системи, привели до гострої необхідності створення і розробки ефективних методів надання допомоги засудженим, технологій їх постпенітенціарної реабілітації, а також опису ролі та змісту соціально-виховної діяльності у пенітенціарних установах.

Порушники законів підривають встановлений порядок, заважають нормальному життю громадян, створюють загрозу безпеці суспільства. Для забезпечення стабільності та громадського порядку, а також безпеки громадян держава покликана домагатися дотримання чинного законодавства, караючи його порушників. Відповідно, певна категорія людей у суспільстві за адміністративно-правові порушення несуть покарання.

Більшість засуджених самостійно подолати свої соціальні проблеми не можуть. Отже, об'єктивно необхідна організація професійної соціальної роботи із цією категорією громадян.

Соціальна робота має міждисциплінарний характер, а тому iii організація за умов пенітенціарних установ дозволяе використовувати у своїй діяльності методики різних наук. У пенітенціарній соціальній роботі особливо важли- вим $є$ те, що вона має універсальний характер, а це дозволяє максимально точно і правильно розглянути проблему кожного клієнта і побудувати оптимальний саме для нього вихід із проблеми, чого не може зробити ні психологія, яка розглядає тільки психологічні аспекти, ні право, що розглядає тільки правову сторону проблеми. Соціальна робота дозволяє побачити весь спектр умов, необхідних для допомоги клієнту.

У зв'язку із цим професійна підготовка повинна бути спрямована на формування у майбутніх фахівців із соціальної роботи таких знань, умінь і навичок, які би дозволили йому грамотно та кваліфіковано проектувати програму роботи із клієнтом, орієнтуючись на досягнення значних позитивних змін особистісних якостей і поведінки. Слід враховувати необхідність формування знань у сфері не тільки соціальної роботи та методики іiї здійснення, а й психології, педагогіки, медицини, права.

Аналіз останніх досліджень і публікацій. Аналіз публікацій із досліджуваної проблеми показав, що соціальна робота 3 реабілітації, адаптації людей з інвалідністю, соціальної підтримки та соціального захисту малозабезпечених сімей, осіб без певного місця проживання та інших категорій досить добре теоретично обгрунтована, тоді як теоретичні основи соціальної роботи в установах пенітенціарної системи у вітчизняній науці розроблені недостатньо. Можливо, це зумовлено тим, що особи, котрі відбувають покарання в місцях позбавлення волі, донедавна розглядалися як об'єкти, які не потребують соціальної підтримки та захисту з боку працівників системи соціального захисту, а лише відбувають справедливе покарання за вчинені правопорушення та соціальний захист на яких не може поширюватися. 
Питання теорії та практики соціальної роботи з різними категоріями засуджених розглядається у працях І. Звєрєвої, А. Капської, В. Лютого, С. Стефанов, С. Харченка, С. Холостової. Зарубіжний досвід соціальної роботи 3 ув'язненими описують у своїх дослідженнях С. Дубінський, М. Галагузова, П. Гусак, М. Колодяжний, М. Турчина, С. Чернета та ін.

Метою статті $\epsilon$ аналіз професійної діяльності соціальних працівників у пенітенціарних закладах.

Виклад основного матеріалу. Соціальна робота із засудженими є одним із видів пенітенціарної роботи, яку можна визначити як специфічний вид професійної діяльності, що включає в себе: соціальну допомогу, підтримку, захист засуджених, сприяння у працевлаштуванні особам, котрі вийшли із місць позбавлення волі; створює передумови для їх виправлення в період відбування покарання, а також ресоціалізації після звільнення.

3 метою реалізації міри покарання за скоєні злочини діє пенітенціарна система держави.

Пенітенціарна система (від лат poenitentia - розкаяння) - державний інститут, який відає виконанням кримінальних покарань, накладених на громадян відповідно до закону. Вона забезпечує виконання покарання у вигляді: позбавлення волі, обмеження волі, утримання підслідних із моменту взяття під варту до суду та покарань, не пов'язаних із позбавленням волі (таких як виправні роботи, громадські роботи, позбавлення права обіймати посади або займатися діяльністю на певний строк), а також нагляд за особами, яких на підставі ст. 75 КК України звільнено від відбування покарання з випробуванням іспитовим строком на певний термін (Пенітенціарна система. Вікіпедія).

У підпорядкуванні пенітенціарної системи перебувають виховні колонії, колонії різного рівня безпеки, слідчі ізолятори, виправні центри та кримінально-виконавчі інспекції.

До основних завдань пенітенціарної системи можна віднести:

1) формування та реалізацію державної політики у сфері виконання кримінальних покарань і пробації;

2) дотримання прав людини;

3) виконання кримінальних покарань і пробації, а також тримання під вартою;

4) гуманізацію умов тримання під вартою;
5) створення умов для соціальної реабілітації та реінтеграції засуджених осіб і вжиття інших заходів, передбачених Законом, щоб засуджені у майбутньому могли жити та жили, не вчиняючи злочинів;

6) всебічне забезпечення умов проходження служби персоналом пенітенціарної системи (Проект закону України «Про пенітенціарну систему», 2017).

Соціальна робота із засудженими регламентується такими нормативно-правовими документами, як: Конституція України (1996р.), Кримінальний кодекс України (2002р.), Кримінально-виконавчий кодекс України (2020р.), Закон України «Про державну кримінальновиконавчу службу в Україні» (2007р.), Загальна декларація прав людини (1948р.), Конвенція про захист прав людини та основоположних свобод (1997р.), Європейські в'язничні правила (2006 р.), Мінімальні стандартні правила ООН щодо поводження з в'язнями (2015р.) та рядом інших міжнародно-правових актів.

Протягом останнього десятиліття в Україні формуються нові підходи до організації виконання кримінальних покарань, засновані на дотриманні прав, свобод і законних інтересів засуджених, що відповідають прийнятим міжнародним нормам і стандартам поводження з ними.

Перебування людини під вартою накладає істотний відбиток на розвиток іiі особистості. На жаль, виходячи 3 місць позбавлення волі, колишні ув'язнені часом не можуть знайти собі місця в житті серед суспільства, що зрештою призводить до вчинення протиправних дій повторно.

Серед негативних соціальних явищ, які сприяють повторному вчиненні злочину, варто зазначити такі:

- засуджений втрачає звичне середовище, статус у суспільстві та набуває особливе правове становище зі специфічними обов'язками;

- примусовий і жорстко регламентований характер ізоляції від суспільства $є$ психотравмуючим фактором і сприяє у деяких засуджених розвитку апатії, депресії, відчуття неповноцінності та незахищеності;

- засуджені, перебуваючи у виправних закладах, значною мірою позбавлені самостійності, частково відвикають піклуватися про свою долю, звикають в усьому покладатися на «передбачливість» адміністрації. 
У зв'язку із цим постає необхідність будувати роботу із засудженими таким чином, щоб із виправних установ виходили громадяни, здатні активно жити, працювати та самореалізуватися у суспільстві. Особи, котрі звільнилися 3 місць позбавлення волі, повинні поповнювати людські ресурси, а не вливатися у криміногенне середовище, створюючи небезпеку рецидиву злочинів і погрожуючи соціальному благополуччю країни.

Соціальна робота у пенітенціарних закладах України розвивається як особливий вид діяльності 3 надання соціальної допомоги та підтримки, здійснення соціального захисту засуджених. Для здійснення саме цього виду діяльності створені відділи соціально-психологічної роботи та групи соціального захисту й обліку трудового стажу засуджених.

Як наголошує О. Васильченко, специфіка соціальної роботи у пенітенціарних закладах полягає в тому, що:

- «вона ведеться усередині соціальних організмів із високим ступенем закритості й ізольованості;

- iї об'єктом є особи з високим індексом соціального неблагополуччя i підвищеною стресогенністю;

- соціальна робота нерозривно пов'язана з виконанням кримінального покарання;

- соціальна робота за умов пенітенціарної системи не повинна припинятися із закінченням виконання покарання, оскільки колишній ув'язнений потребує ресоціалізації й адаптації до зовнішнього світу, його правил і норм» (Васильченко, 2013: 34).

Визначальним критерієм соціальної орієнтованості роботи за умов пенітенціарної системи $\epsilon$ дотримання низки принципів. Окрім відомих філософських і загальнонаукових принципів соціальної роботи, виділяють специфічні, найбільш важливими серед яких є принципи: універсальності, охорони соціальних прав, профілактики, соціального реагування, клієнтоцентризму, конфіденційності, толерантності, опори на власні сили, максимізації соціальних ресурсів.

Прогресуюче зростання кількості правопорушень у молодіжному середовищі висувають перед суспільством завдання пошуку ефективних форм, методів і технологій роботи 3 різними групами та насамперед із групами осіб із девіантною та делінквентною поведінкою.
Важливою є організація соціальної роботи 3 підлітками та молоддю. І. Дубровіна, даючи характеристику неповнолітнім правопорушникам, передусім наголошує на тому, що «загальний фізичний, психічний розвиток таких дітей відрізняється від розвитку однолітків. У них спостерігається сповільнений темп психічного розвитку, низка негативних особливостей: низький рівень інтелектуального розвитку, бідні емоційна сфера й уява, пізнє формування навиків саморегуляції та правильної поведінки» (Дубровина, 1995).

За соціологічними даними, «у 12\% неповнолітніх злочинців наявна психопатія, у 50\% акцентуації характеру (60\% - нестійкого типу; $20 \%$ - гіпертимного типу), що призводить до ускладнення самоконтролю, поведінкової нестійкості» (Шанскова, 2006: 50-53).

Складність природи девіантної поведінки молоді висуває серйозні вимоги до спеціалістів для соціальної роботи у пенітенціарних закладах.

Наголосимо на тому, що фахівці соціальної сфери повинні бути професійно орієнтовані на вивчення особливостей внутрішнього світу деформованої особистості, кримінального середовища і підготовлені не до боротьби 3 ними, а до надання їм всебічної допомоги; впливу на психіку i поведінку засуджених із використанням психолого-педагогічних методів і гуманістичних технологій, які спонукають особистісну активність самих засуджених на власне виправлення і формування сприятливого мікросередовища. Перед ними стоїть завдання психологічного та соціального забезпечення діяльності персоналу установ і органів виконання покарань (Галагузова, 2002: 20).

За сучасних умов важливим завданням пенітенціарної системи виступає ідея ресоціалізації засуджених.

У словниках ресоціалізація розглядається як «1) відновлення особистістю якостей, необхідних для нормальної життєдіяльності у суспільстві; 2) засвоєння нових цінностей, ролей, навичок замість попередніх; 3) комплекс заходів, спрямований на відновлення соціального статусу особистості, втрачених або несформованих соціальних навичок, переорієнтація соціальних і референтних орієнтацій девіантів через включення їх у нові, позитивно орієнтовані стосунки й види діяльності» (Безпалько, Капська, 2005). 
На думку М. Шоу, фахівець із соціальної роботи із засудженими повинен виконувати такі види діяльності:

1) оцінку ризику небезпеки засудженого для себе та інших; оцінку особистих і соціальних потреб засудженого; оцінку ризику рецидиву (у співпраці з іншими фахівцями);

2) здійснення стратегічного планування;

3) консультування фахівців пенітенціарної системи (персоналу виправних установ), в тому числі організацію і проведення навчальних занять для них;

4) роботу із сім'ями засуджених та іншими членами їх соціального оточення, в тому числі й за допомогою інших фахівців соціальної роботи (наприклад, тих, хто здійснює власну професійну діяльність за межами виправної установи);

5) реалізацію індивідуальної та / або групової роботи із засудженими; профілактику залежної поведінки; допомогу засудженому у процесі його підготовки до звільнення;

6) координацію програм i / або заходів, що здійснюються різними організаціями та спрямовані на зниження ризику повторних правопорушень;

7) оцінку та моніторинг соціальних програм, які реалізуються в установах пенітенціарної системи (Shaw, 1974).

До основних напрямів соціальної роботи із засудженими відносять «спеціально організоване всебічно моральне, правове, трудове, естетичне, фізичне, санітарно-гігієнічне виховання, а також інші його види, що сприяють вибору засудженими такої життєвої позиції, яка відповідає правовим нормам і вимогам суспільнокорисної діяльності» (Олексюк, 2018: 86).

Правове виховання засуджених $€$ процесом формування правосвідомості, що включає знання принципів і норм права та переконання в необхідності дотримуватися їх, а також організацію правомірної, відповідальної та соціально активної поведінки. Його завдання полягає в тому, щоб максимально домагатися засвоєння засудженими знань основних законів держави і на цій основі сприяти формуванню у них високої правосвідомості.

Моральне виховання засуджених виступає важливим механізмом у профілактиці злочинності серед осіб іє цілеспрямованою діяльністю державних і недержавних суб'єктів профілак- тики, яка зводиться до подолання у засуджених чужих суспільству моральних якостей і переконань. Результатом соціальної роботи має виступити формування у засуджених моральних почуттів, свідомості та моральної поведінки.

Трудове виховання засуджених зводиться до закріплення у індивідів, котрі входять до цієї групи, трудових умінь і навичок, психологічної готовності до праці, усвідомленої потреби трудитися.

Фізичне та санітарно-гігієнічне виховання засуджених - це діяльність, що не допускає деградацію особистості засудженого, зберігає його людську гідність, спрямована на розвиток фізичних здібностей, зміцнення здоров'я, формування морально-вольових якостей (Харченко, Караман, Краснова, 2011).

Фахівці із соціальної роботи пенітенціарної установи орієнтовані на індивідуальну роботу 3 кожним засудженим, профілактику соціального неблагополуччя, допомогу у подоланні важких життєвих ситуацій, сприяння вирішення виникаючих або наявних соціальних проблем як всередині виправної установи, так і в зовнішньому соціумі. Особлива роль фахівця iз соціальної роботи пенітенціарної установи полягає у відновленні втрачених або ослаблених соціальних зв'язків засудженого, його взаємин із родичами та найближчим оточенням, що сприяє відновленню його правосвідомості та громадянського статусу. Найбільш відповідальним $\epsilon$ етап підготовки засудженого до звільнення і його перші кроки у вільному суспільстві, які обов'язково повинні супроводжуватися якнайшвидшою адаптацією засудженого до соціуму, його працевлаштуванням і поверненням у сім'ю. Цей етап найбільшою мірою залежить від майстерності та професіоналізму фахівця із соціальної роботи, що зумовлені умінням встановити контакт і взаєморозуміння як із самим засудженим, так і з людьми, від яких залежить успішність адаптації засудженого у соціумі після звільнення, а також рішення його соціальних проблем (Харченко, Караман, Краснова, 2011).

Системний підхід у роботі із засудженим $\epsilon$ системою здійснюваних соціально-педагогічних, психологічних заходів, спрямованих на отримання всебічно повних відомостей, що характеризують його особу, з метою найбільш ефективного застосування методів, прийомів 
і засобів переконання, виправлення, перевиховання, а також допомоги та прогнозування його поведінки.

Психологічні аспекти у пенітенціарній соціальній роботі проявляються у таких напрямах, як:

- вивчення особистості засудженого і становлення його «злочинної кар'єри»;

- розробка індивідуальних програм впливу та допомоги засудженому;

- соціально-психологічна допомога в адаптації засудженого до середовища виправної установи;

- соціально-психологічна i професійна допомога у підготовці до виходу із місць позбавлення волі (Аушева, 2013: 48).

Виділяють три групи якостей соціального працівника, котрий здійснює діяльність в установах пенітенціарної системи: 1) індивідуальнопсихологічні характеристики, які є складовою частиною здатності до цього виду діяльності; 2) професійно важливі якості, орієнтовані на вдосконалення соціального працівника як спеціаліста-професіонала; 3) соціально-психологічні якості, спрямовані на створення ефекту особистої привабливості.

До першої групи якостей можна віднести вимоги, що висуваються професійною діяльністю до психічних процесів: сприйняття, пам'яті, уяви, мислення; емоційних (стриманості, індиферентності) і вольових (наполегливості, послідовності, імпульсивності) характеристик. Деякі із цих психологічних основ $€$ головними, без яких взагалі неможлива якісна професійна діяльність.

До другої групи належать якості, спрямовані на вдосконалення фахівця як особистості, як працівника. Це самоконтроль, самокритичність, а також стресостійкі якості - фізична тренованість, самонавіювання, вміння переключитися і керувати емоціями.

До третьої групи якостей належать комунікабельність, емпатійність, візуальність (зовнішня привабливість особистості), красномовність тощо. Третя група якостей базується на деяких психологічних теоріях комунікацій (самопрезентація або самопред'явлення). Умінням правильно «подати себе» повинен володіти фахівець у будь-якій сфері соціальної взаємодії.

Світова та вітчизняна практика пенітенціарної соціальної роботи, вимоги, які висуваються суспільством і державою до фахівця, показують, що для здійснення ефективної професійної діяльності фахівця із соціальної роботи у пенітенціарній установі необхідна система підвищення кваліфікації, що дозволяє зберігати професійні й особистісні ресурси фахівців, вдосконалювати професійну майстерність, підвищувати рівень професійної культури.

Водночас специфіка складного контингенту й особливості середовища професійної діяльності вимагають постійного самовдосконалення і професійного зростання фахівця із соціальної роботи пенітенціарної установи.

Від фахівців вимагається бути поінформованими про запроваджені новації, засвоювати, апробувати та транслювати їх у власну професійну практику. Отже, співробітники повинні на різних етапах роботи мати можливість отримувати знання, вивчати передовий досвід вітчизняної та зарубіжної пенітенціарної соціальної роботи.

У роботі фахівців із соціальної роботи пенітенціарних установ необхідно враховувати весь спектр складнощів роботи з важким «людським матеріалом». Професійний функціонал фахівця iз соціальної роботи передбачає тісний особистісний контакт із контингентом виправних установ і облік індивідуальних особливостей кожного засудженого. Такі особливості професійної діяльності вказують на перевагу індивідуальної роботи із засудженими. Крім того, необхідно враховувати той факт, що тривала робота зі складним контингентом, інтенсивність праці, умови ізоляції та інші численні фактори призводять до професійної деформації особистості фахівця.

Висновки. Отже, діяльність соціального працівника у пенітенціарній установі $є$ актуальною та потрібною, а також має свої особливості, пов'язані зі специфічним контингентом.

Здійснюючи свою професійну діяльність, соціальний працівник повинен опиратися на принципи законності, справедливості та гуманізму, оскільки на практиці ці принципи більше мають декларативний характер. Одне із завдань соціального працівника полягає в тому, щоб не тільки самому дотримуватися цих принципів щодо засуджених, а й стежити за тим, щоб вони дотримувалися іншими співробітниками пенітенціарної установи стосовно осіб, які відбувають покарання. 


\section{ЛІТЕРАТУРА:}

1. Аушева В.А. Инновационные подходы и особенности социальной работы в пенитенциарных учреждениях. Человеческий капитал. 2013. № 7. С. 44-49.

2. Васильченко О.А. Соціальна робота в пенітенціарній системі: сучасний стан і перспективи розвитку. Грані. 2013. № 12. C. 31-37.

3. Пенітенціарна система. Вікіnедія. URL: https://uk.wikipedia.org/wiki/Пенітенціарна_система.

4. Галагузова М.А. Социальная работа с осужденными : учебное пособие. Москва : МГСУ, 2002. 210 с.

5. О развитии детей, оставшихся без родительского попечения : Очерки / И.В. Дубровина, Э.А. Минкова, М.К. Бардышевская. Москва : ТОО «СИМС», 1995. 64 с.

6. Олексюк Н.С. Соціальна реабілітація осіб, які перебували у конфлікті із законом. Соціальна робота: виклики сьогодення : матеріали VII Всеукраїнської науково-практичної конференції (Тернопіль, 26-27 квітня 2018 р.). Тернопіль, 2018. С. 86-88.

7. Пенітенціарна педагогіка : науково-методичний посібник / С.Я. Харченко, О.Л. Караман, Н.П. Краснова ; Держ. закл. «Луган. нац. ун-т імені Тараса Шевченка». Луганськ : Вид-во Д3 «ЛНУ імені Тараса Шевченка», 2011. 329 с.

8. Про пенітенціарну систему : Проект закону України від 24 листопада 2017 p. № 7337 URL: http://search. ligazakon.ua/1_doc2.nsf/link1/JH5NT00A.html (дата звернення: 16.08.2021).

9. Словник-довідник для соціальних працівників та соціальних педагогів / уклад. О.В. Безпалько та ін. ; ред. А.Й. Капська та ін. Київ : УДЦССМ, 2005. 258 с.

10. Шанскова T.I. Аналіз причин правопорушень неповнолітніх як підгрунтя соціально-педагогічної роботи 3 молоддю щодо профілактики злочинності. Вісник Житомирського державного університету ім. I. Франка. 2006. № 30. C. 50-53.

11. Shaw M. Social Work in Prison. HORS 22. London : HMSO, 1974.

\section{REFERENCES:}

1. Ausheva V.A. (2013) Innovatsionnye podkhody i osobennosti sotsialnoy raboty v penitentsiarnykh uchrezhdeniyakh [Innovative approaches and features of social work in penitentiary institutions.]. Chelovecheskiy kapital - Human capital, 7, 44-49 [in Russian].

2. Vasylchenko O.A. (2013). Sotsialna robota v penitentsiarnii systemi: suchasnyi stan i perspektyvy rozvytku [Social work in the penitentiary system: current status and prospects]. Hrani - Faces, 12, 31-37 [in Ukrainian].

3. Penitentsiarna systema. [Penitentiary system]. Vikipediia. - Wikipedia Retrieved from: https://uk.wikipedia.org/ wiki/Пенітенціарна_ система [in Ukrainian].

4. Halahuzova M.A. (2002). Sotsialnaya rabota s osuzhdennymi: uchebnoe posobiye [Social work with convicts: study guide]. Moskva: МГCУ [in Russian].

5. Dubrovina I.V., Minkova E.A. Bardyshevskaya M.K. (1995). O razvitii detey. ostavshikhsya bez roditelskogo popecheniya : Ocherki [On the development of children without parental care: Essays]. Moskva: ТОО СИМС [in Russian].

6. Oleksiuk, N.S. (2018). Sotsialna reabilitatsiia osib, yaki perebuvaly u konflikti iz zakonom. [Social rehabilitation of persons who were in conflict with the law] Sotsialna robota: vyklyky sohodennia: - Social work: challenges of today: materials of the VII All-Ukrainian scientific-practical conference (pp. 86-88). Ternopil [in Ukrainian].

7. Kharchenko S., Karaman, O., Krasnova N. (2011) Penitentsiarna pedahohika [Penitentiary pedagogy]. Luhansk: Vyd-vo DZ "LNU imeni Tarasa Shevchenka" [in Ukrainian].

8. Pro penitentsiarnu systemu: Proekt zakonu Ukrainy [On the penitentiary system: Draft law of Ukraine]. Retrieved from http://search.ligazakon.ua/__doc2.nsf/link1/JH5NT00A.html [in Ukrainian].

9. Bezpalko O., Kapska A. (Eds.) (2005). Slovnyk-dovidnyk dlia sotsialnykh pratsivnykiv ta sotsialnykh pedahohiv [Dictionary-reference book for social workers and social educators]. Куiv: УДЦССМ [in Ukrainian].

10. Shanskova T. I. (2006) Analiz prychyn pravoporushen nepovnolitnikh yak pidgruntia sotsialno-pedahohichnoi roboty z moloddiu shchodo profilaktyky zlochynnosti [Analysis of the causes of juvenile delinquency as a basis for sociopedagogical work with youth on crime prevention]. Visnyk Zhytomyrskoho derzhavnoho universytetu im. I. Franka.Bulletin of Zhytomyr State University. I. Franko, 30, 50-53 [in Ukrainian].

11. Shaw M. (1974) Social Work in Prison. HORS 22. London: HMSO. 